\title{
“ANALISIS IMPLEMENTASI KEBIJAKAN E-FAKTUR DALAM UPAYA PENINGKATAN PENERIMAAN NEGARA PADA KPP PRATAMA TEBET TAHUN 2016"
}

\author{
Idar Rachmatulloh dan Putri Y. Pamungkas \\ Institut Ilmu Sosial dan Manajemen STIAMI \\ idarrachmatulloh@gmail.com
}

\begin{abstract}
Abstrak. Pada 2013-2014 nilai faktur pajak fiktif meningkat mencapai Rp 150.600.000.000,00, untuk itu Direktorat Jenderal Pajak berupaya menciptkan kebijakan yaitu e-faktur dengan tujuan untuk menghilangkan jumlah faktur pajak fiktif yang akan mampu meningkatkan penerimaan negara. Penelitian ini dalam implementasinya menggunakan teori Edward III. Dalam penelitian ini peneliti ingin mengetahui implementasi e-Faktur yang sudah diterapkan dari awal percobaan pada Jawa dan Bali di tahun 2015 dan berlaku secara nasional pada Juli 2016. Dalam penelitian ini peneliti menggunakan metode penelitian kualitatif yang merupakan analisis data uraian deskriptif membandingkan antara realisasi penerimaan dengan potensi e-Faktur terkait penerimaan Negara. Dari hasil penelitian, pada tahun 2015 saat e-faktur diterapkan tahap pertama di Jawa dan Bali meningkat dari tahun 2014 dimana e-faktur belum diberlakukan. Dan pada tahun 2016 saat e-faktur ditetapkan skala nasional, penerimaan Negara meingkat 12,40\%. Hal ini menjelaskan bahwa efaktur dapat membantu untuk meningkatkan penerimaan Negara.
\end{abstract}

Kata Kunci: Implementasi, Penerimaan Negara, E-Faktur, Pajak Pertambahan Nilai

Abstract. In 2013 - 2014 value an invoice tax fictitious up by Rp.150.600.000.000,00, for that Direktorat Jenderal Pajak is trying to create E-Faktur for the purpose of removing the number of an invoice tax fictitious would encourage state revenues. This research in its implementation use the theory Edward III. In this research researchers want to know the implementation of E-Faktur that had taken from the beginning experiments on Java and Bali in 2015 and are valid nationwide in July 2016 .In this research researchers used research methodology qualitative is data analysis the discussion descriptive comparing between the realization of with the potential E-Faktur related state revenues. The research, in 2015 when E-Faktur applied the first phase in Java and Bali increase from 2014 where E-Faktur has not been applied yet. And on 2016 when E-Faktur set of the national scale, state revenues increase to $12,40 \%$.This explains that E-Faktur can help to improve state income .

Key Words: Implementation, National Income, E-Faktur, Value-Added Tax

Berkembangnya suatu negara akan memengaruhi teknologi yang digunakan oleh masyarakat di dalamnya. Masyarakat akan cenderung mencari teknologi yang lebih baik dari sebelumnya untuk dapat mempercepat pekerjaanya. Penggunaan teknologi informasi baru atau penggantian pemakaian teknologi informasi baru dapat mengubah perilaku individu dalam organisasi. Perubahan merupakan sesuatu yang harus dilakukan karena tanpa adanya perubahan, maka tidak akan ada perbaikan.

Pemerintah juga menggunakan teknologi informasi untuk memperbaiki penerimaan pajak. Pemerintah memutuskan untuk mengganti faktur pajak kertas menjadi faktur pajak elektronik. Faktur pajak merupakan bukti pungutan pajak yang dibuat oleh pengusaha kena pajak karena penyerahan barang kena pajak atau penyerahan jasa kena 
Idar Rachmatulloh dan Putri Y. Pamungkas, Analisis Implementasi Kebijakan E-Faktur...

pajak atau bukti pungutan pajak karena impor barang kena pajak yang digunakan oleh Direktorat Jenderal (Waluyo, 2011:315). Faktur pajak berfungsi sebagai bukti pungutan pajak dan dapat digunakan sebagai sarana untuk mengkreditkan pajak masukan. Perubahan dari faktur pajak kertas menjadi faktur pajak elektronik ini dilandasi karena adanya individu yang tidak bertanggungjawab yang membuat faktur pajak fiktif.

Pada 2010-2012 nilai faktur pajak fiktif mencapai Rp100.000.000.000,00 dan pada 2013-2014 nilai faktur pajak fiktif meningkat mencapai Rp 150.600.000.000,00 (Minggu Pertama Satgas Faktur Pajak Fiktif Kanwil DJP Jawa Tengah I Peroleh Rp 5,9 m, 2015). Pemerintah berupaya mengurangi jumlah faktur pajak fiktif dengan membuat peraturanperaturan baru.

Pemerintah menetapkan untuk mengganti faktur pajak kertas menjadi faktur pajak elektronik. Dasar hukum dari faktur pajak elektronik adalah UU Nomor 42 Tahun 2009 tentang Perubahan Ketiga atas UU Nomor 8 TAHUN 1983 tentang PPN Barang dan Jasa dan PPnBM. PMK-151/PMK.03/2013 tentang Tata Cara Pembuatan dan Tata Cara Pembetulan atau Penggantian Faktur Pajak. PER-17/PJ/2014 tentang Perubahan Kedua atas PER-24/PJ/2012 tentang Bentuk, Ukuran, Prosedur Pemberitahuan dalam Rangka Pembuatan, Tata Cara Pengisian Keterangan, Pembetulan atau Penggantian, dan Pembatalan Faktur Pajak. PER16/PJ/2014 tentang Tata Cara Pembuatan dan Pelaporan Faktur Pajak Berbentuk Elektronik. Peraturan Menteri Keuangan nomor 151/PMK.03/2013, KEP- 136/PJ/2014, peraturan Direktur Jenderal Pajak nomor PER-16 /PJ/2014, dan PER-17/PJ/2014 tentang perubahan kedua atas peraturan Direktur Jenderal Pajak nomor PER24/PJ/2012. Pemberlakuan faktur pajak elektronik secara bertahap ini ditetapkan di dalam KEP-136/PJ/2014. Pada tahap pertama penggunaan faktur pajak elektronik akan diimplementasikan pada Juli 2014 untuk 45 pengusaha kena pajak tertentu yang terdaftar atau dikukuhkan di KPP di lingkungan
Kanwil DJP wajib pajak besar, KPP di lingkungan Kanwil DJP Jakarta khusus, dan KPP Madya di Jakarta ditambah satu pengusaha kena pajak pada bulan November 2014. Sebelum memutuskan untuk mengimplementasikan kepada 45 pengusaha kena pajak, terlebih dulu dilakukan uji coba aplikasi faktur pajak elektronik pada November dan Desember 2013 oleh satu pengusaha kena pajak untuk masing-masing Kantor Pelayanan Pajak dengan cara melakukan testing aplikasi faktur pajak elektronik kemudian memberikan penilaian dan masukan. Kegiatan ini akan dilanjutkan dengan pilot project aplikasi faktur pajak elektronik pada Januari sampai Juni 2014 oleh 5 pengusaha kena pajak untuk masingmasing Kantor Pelayanan Pajak. Pada tahap ini, lima sampel pengusaha kena pajak di setiap Kantor Pelayanan Pajak sudah menggunakan aplikasi faktur pajak elektronik dengan infrastruktur yang sebenarnya dan dapat terhubung dengan sistem Direktorat Jenderal Pajak. Tahap kedua dilakukan pada 1 Juli 2015 yang diberlakukan kepada seluruh pengusaha kena pajak di pulau Jawa dan Bali. Tahap terakhir dilakukan pada 1 Juli 2016 yang diberlakukan untuk semua pengusaha kena pajak di Indonesia.

Direktur Penyuluhan, Pelayanan dan Hubungan Masyarakat Ditjen Pajak, Mekar Satria Utama mengungkapkan, jumlah tersebut berdasarkan update per 1 Januari 2016. "Data tersebut berdasarkan perhitungan diaplikasi quick count di 26 KPP dan juga hasil aplikasi e-faktur," jelasnya saat berbincang dengan wartawan di kantornya, Jakarta, Senin (13/4/2015). Mekar pun merincikan, untuk wajib pajak perorangan, total SPT yang dilaporkan pada 2015 mencapai 9,92 juta wajib pajak. jumlah tersebut naik 17,58 persen jika dibanding dengan periode yang sama tahun lalu. Sedangkan untuk wajib pajak badan, jumlah pelaporan mencapai 164.359 wajib pajak, jumlah tersebut naik 33,13 persen jika dibanding dengan tahun sebelumnya yang jumlahnya hanya sekitar 123.459 wajib pajak. 
Penelitian ini akan dilakukan dengan metode kualitatif. Penelitian kualitatif menurut Moleong (2013: 6) adalah penelitian yang bermaksud untuk memahami fenomena yang dialami subjek penelitian dengan menjabarkan secara deskripsi dalam bentuk kata-kata dan bahasa pada suatu konteks khusus yang alamiah dan dengan memanfaatkan berbagai metode ilmiah. Data penelitian diperoleh dengan melakukan wawancara pada perusahaan. Wawancara akan dilakukan di KPP Pratama Tebet sebagai objek penelitian.

Pada prinsipnya kebijakan penggunaan Faktur Pajak Elektronik menjadikan tiap perusahaan yang menggunakannya memiliki sistem terintegrasi untuk mempermudah wajib pajak dalam membuat faktur pajak dengan sistem paperless. Tetapi pada pengaplikasiannya masih ditemukan banyak kendala terkait sistem maupun aplikasi e-faktur. Seperti, Error Maintence pada sistem yang belakangan sering terjadi dikarnakan sistem yang tidak kuat menapung banyaknya log in dalam satu waktu yang sama. Dan juga kendala terkait aplikasi e-faktur, salah satunya yang sering terjadi adalah ETAX-10002 tidak dapat mengambil data, dan yang sering terjadi juga ETAX-20008 error validasi. Masih banyak error - error yang dapat terjadi dalam aplikasi faktur pajak elektronik.

Dari penjelasan di atas maka peneliti tertarik untuk mengambil "Analisis Implementasi Kebijakan E-Faktur Dalam Upaya Peningkatan Penerimaan Negara Pada KPP Pratama Tebet TAhun 2016" yang akan dibahas pada bab selanjutnya.

\section{Pertanyaan Penelitian}

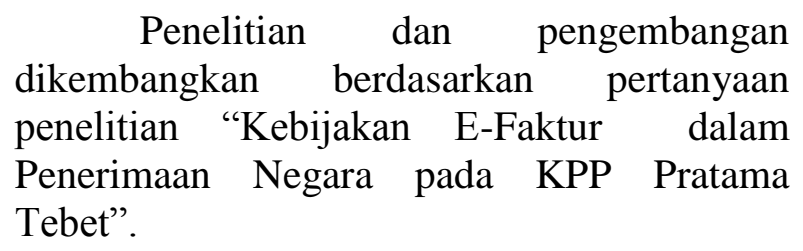

Pertanyaan penelitian tersebut dapat dirinci sebagai berikut :
1. Bagaimana Implementasi kebijakan EFaktur di Kantor Wilayah KPP Pratama Tebet Jakarta Selatan dalam rangka meningkatkan Penerimaan Negara Tahun 2016 ?

2. Bagaimana faktor-faktor penghambat yang terjadi selama implementasi kebijakan e-faktur?

3. Bagaimana target penerimaan di KPP Pratama Tebet pasca diberlakukannya EFaktur?

\section{Kerangka Pemikiran dan Model}

Metode penelitian merupakan penjelasan secara teknis mengenai metode metode yang digunakan dalam suatu penelitian. (Noeng Muhadjir, Metodologi Penelitian Kualitatif, 1992). Atau dengan kata lain, pada metode penelitian akan membahas mengenai keseluruhan cara suatu penelitian, yang mencakup prosedur dan teknik- teknik yang dilakukan di dalam penelitian, seperti tipe penelitian, pendekatan penelitian, dan metode pengumpulan data yang dilakukan. Lihat gambar 1.

\section{Pendekatan dan Jenis Penelitian}

Pada hakikatnya sebuah penelitian adalah pencarian jawaban dari pertanyaan yang ingin diketahui jawabannya oleh peneliti. Selanjutnya hasil penelitian akan berupa jawaban atas pertanyaan yang diajukan pada saat dimulainya penelitian. Untuk menghasilkan jawaban tersebut dilakukan pengumpulan, pengolahan, dan analisis data dengan menggunakan metode tertentu.

Pendekatan penelitian yang digunakan dalam penelitian ini adalah pendekatan kualitatif. Dalam penilitian kualitatif digunakan untuk menunjukan hubungan antarvariabel, menguji relevansi suatu teori dan mendapatkan generalisasi yang memiliki kemampuan prediktif. Teknik penelitian ini menggunakan instrumen wawancara secara mendalam kepada informan untuk menjelaskan mengenai penggunaan sistem faktur pajak elektronik. Selain itu peneliti 
Idar Rachmatulloh dan Putri Y. Pamungkas, Analisis Implementasi Kebijakan E-Faktur...

melakukan observasi langsung ke dalam site penelitian.

Penelitian kualitatif adalah suatu pendekatan yang juga disebut pendekatan investigasi karena biasanya peneliti mengumpulkan data dengan cara bertatap muka langsung dan berinteraksi dengan orang-orang di tempat penelitian (McMillan \& Schumacher, 2003).

Gambar 1. Ilustrasi model konseptual :

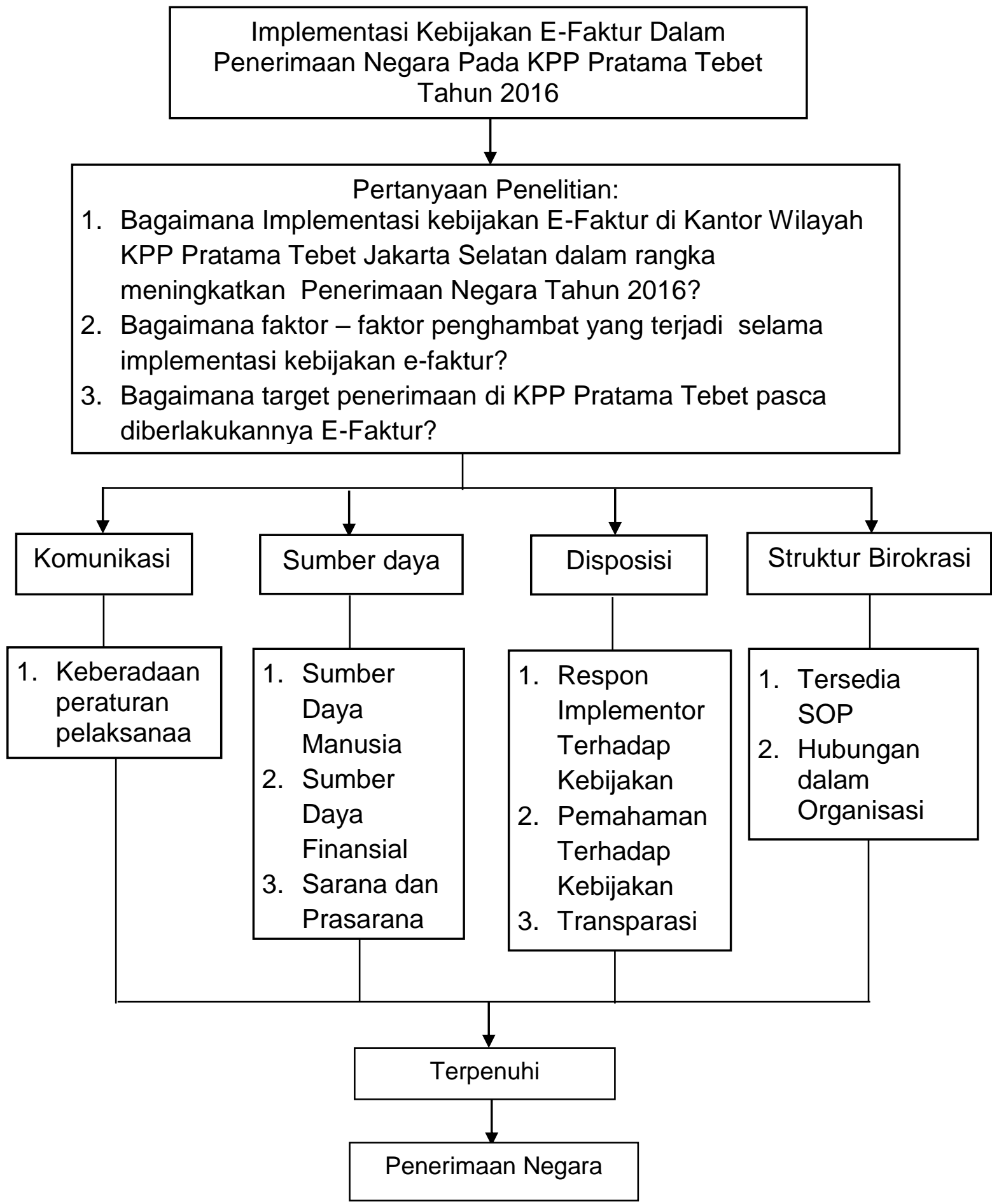


REFORMASI ADMINISTRASI

Jurnal Ilmiah Untuk Mewujudkan Masyarakat Madani ISSN 2355-309X

\section{Teknik Pengumpulan Data}

Wawancara

Untuk mendapatkan data peneliti melakukan wawancara secara mendalam. Tujuannya untuk mendapatkan informasi maupun pendirian secara lisan seorang responden, dengan wawancara tatap muka. Pertanyaan yang dilakukan kepada informan dilakukan secara terbuka dan melakukan one by one interview dengan audio tape dengan tujuan supaya penilti dapat mengetahui jawaban dengan tepat dan jelas. Selanjutnya atas hasil tersebut diolah menjadi transkrip wawancara yang nantinya akan di analisis.

\section{Observasi}

Metode observasi adalah pengumpulan data yang dilakukan dengan sengaja, sistematis mengenai fenomena sosial dan gejala-gejala pisis untuk kemudian dilakukan pencatatan. Dalam kaitannya dengan penelitian ini penulis langsung terjun ke lapangan menjadi partisipan (observer partisipatif) untuk menemukan dan mendapatkan data yang berkaitan dengan fokus penelitian, yaitu,Analisis Kebijakan EFaktur dalam Penerimaan Negara di KPP Pratama Tebet Tahun 2016.

\section{Teknik Analisis Data}

Analisis data dalam penelitian kualitatif merupakan tahapan yang terdiri dari kegiatan sistematis untuk membangun kaitan antar data penelitian dalam upaya membentuk makna yang akan dipakai untuk menjawab pertanyaan penelitian.

Penilaian validitas dan reliabilitas penelitian kualitatif:

1. Kredibilitas Kredibel berarti dapat dipercaya dari perspektif partisipan dalam penelitian itu. (Kegiatan untuk meningkatkan kredibilitas: triangulasi, perpanjangan pengamatan, ketekunan penelitian, diskusi teman sejawat, kasus negatif, memberchecking).
Volume 4, No. 2, September 2017

2. Transferabilitas Transferabilitas merujuk pada tingkat kemampuan hasil penelitian kualitatif dapat digeneralisasikan atau ditransfer kepada konteks atau setting yang lain. Dengan kata lain, transferabilitas adalah generalisasi.

3. Dependabilitas Kriteria dependabilitas dalam kualitatif sama dengan raliabilitas dalam kuantitatif. Peneliti penting untuk memperhitungkan konteks yang berubahubah dalam penelitian yang dilakukan dan menjelaskan perubahanperubahan yang terjadi, termasuk menjelaskan bagaimana perubahan tersebut dapat memengaruhi cra pendekatan penelitian.

4. Konfirmabilitas Kriteria konfirmabilitas merujuk pada tingkat kemampuan hasil penelitian dapat dikonfirmasi kepada orang lain. (Kegiatan untuk meningkatkan konfirmabilitas: dokumentasi prosedur untuk mengecek, mengecek data penelitian/ audit data)

Creswell (2010) menyatakan enam langkah analisis data kualitatif:

1. Mengolah dan mempersiapkan data untuk dianalisis.

2. Membaca keseluruhan data.

3. Menganalisis lebih detail dengan mengcoding data.

4. Terapkan proses coding untuk mendeskripsikan setting, orang-orang, kategorikategori dan tema-tema akan dianalisis.

5. Tunjukkan bagaimana deskripsi dan tema-tema ini akan disajikan kembali dalam narasi/ laporan kualitatif.

6. Menginterpretasi atau memaknai data.

Berikut beberapa model analisis data kualitatif menurut Emzir (2010). 
Idar Rachmatulloh dan Putri Y. Pamungkas, Analisis Implementasi Kebijakan E-Faktur...

1. Model Miles and Huberman (Reduksi Data, Data Display, Verifikasi).

2. Model Grounded Strauss dan Corbin (Tiga Jenis Pengodean: Pengodean Terbuka, Pengodean Berporos, Pengodean Selektif).

3. Model Boglan Biklen (Analisis data dan interpretasi di lapangan, Analisis dan interpretasi setelah pengumpulan data, Pengembangan kategori pengkodean).

\section{PEMBAHASAN}

\section{Implementasi Kebijakan E-Faktur di Kantor Wilayah KPP Pratama Tebet Jakarta Selatan dalam Rangka Meningkatkan Penerimaan Negara Tahun 2016}

Di negara berkembang khususnya seperti di Indonesia di mana pemerintah memberikan kemudahan dalam hal perpajakan sering sekali disalahgunakan. Salah satu bentuknya yaitu penyalahgunaan faktur pajak fiktif, sehingga pembayaran pajaknya menjadi berkurang. Faktur Pajak fiktif secara sederhana dapat diartikan sebagai faktur pajak tidak sah, yang membuat tidak sah di sini karena kurang lengkapnya informasi yang dicantumkan ataupun karena antara informasi yang dicantumkan tidak sesuai dengan keadaan yang sebenarnya. Penyebab terjadinya penyalahgunaan faktur pajak fiktif di antaranya yaitu kurangnya fungsi pengawasan, di mana fungsi pengawasan di sini berupa audit kepada PKP untuk memastikan apa yang sudah dilaporkan PKP sesuai dengan keadaan yang sebenarnya, di sini fungsi petugas pajak juga sangat berperan dalam mencegah terjadinya penyalahgunaan faktur pajak fiktif.

Penyalahgunaan faktur pajak fiktif di Indonesia bukanlah hal yang baru, karena nilai faktur fiktif yang terdeteksi pada 20102012 mencapai Rp100 miliar. Kondisi ini terus meningkat pada tahun berikut karena wajib pajak dinilai tidak jera terhadap hukuman. Tercatat nilai faktur fiktif dari 2013-2014 mencapai Rp150,6 miliar.
Dalam semangat Tahun Pembinaan Wajib Pajak 2015, terhadap Wajib Pajak Pengguna Faktur Pajak Tidak Berdasarkan Transaksi yang Sebenarnya (TBTS) yang mengakui perbuatannya dan melakukan pembayaran serta pembetulan SPT Masa PPN terkait tidak akan dilakukan kegiatan penindakan. Selain itu, Wajib Pajak dapat memanfaatkan fasilitas penghapusan sanksi sebagaimana diatur dalam Peraturan Menteri Keuangan Nomor 91/PMK.03/2015. Namun terhadap Wajib Pajak pengguna Faktur Pajak TBTS yang tidak mengakui perbuatannya atau tidak merespon undangan klarifikasi dan terbukti terdapat indikasi tindak pidana perpajakan berupa penggunaan/pengkreditan Faktur Pajak TBTS akan ditindak sesuai hukum yang berlaku.

Kegiatan klarifikasi Satgas 2015 terhadap wajib pajak Pengguna Faktur Pajak TBTS telah dimulai sejak Mei 2015 di Kanwil DJP Banten, Pulau Jawa, Sumatera, dan Kalimantan. Pengguna Faktur Pajak TBTS di DKI Jakarta telah mulai diundang untuk kegiatan klarifikasi sejak tanggal 1 Oktober 2015 hingga Desember 2015. Jumlah keseluruhan data Satgas 2015 dan hasilnya saat ini adalah sebagai berikut pada Gambar 2 .

Keinginan Wajib Pajak untuk patuh dipengaruhi oleh perlakuan ataupun pelayanan yang diberikan oleh otoritas pajak. Semakin baik otoritas pajak dalam memperlakukan Wajib Pajak maka dapat meningkatkan keinginan Wajib Pajak untuk patuh. Selain itu, jika prosedur perpajakan dikomunikasikan secara baik dengan Wajib Pajak maka motivasi untuk mematuhi pajak semakin tinggi. Dan dengan begitu berdampak pada peningkatan penerimaan Negara. Dari pihak KPP Pratama Tebet telah melakukan komunikasi yang baik dengan Wajib Pajak. Seperti yang dikemukakan oleh Richwantoro, S.SI (Kepala Seksi Pelayanan KPP Pratama Tebet). “...penyebaran melalui media sosial, dari pengetahuan wajib pajak itu juga mereka seperti kesadaran datang ke KPP 
Jurnal Ilmiah Untuk Mewujudkan Masyarakat Madani

ISSN 2355-309X

untuk menyakan tentang e-Faktur secara langsung. Dan kami informasikan dengan baik bagaimana-bagaimana tentang e-faktur
tersebut...."(Wawancara 03 Januari 2017, 14.30 WIB).

\section{Gambar 2.}

Hasil Klarifikasi Hasil Kegiatan Klarifikasi Satgas atas Faktur Pajak TBTS Tahun 2015

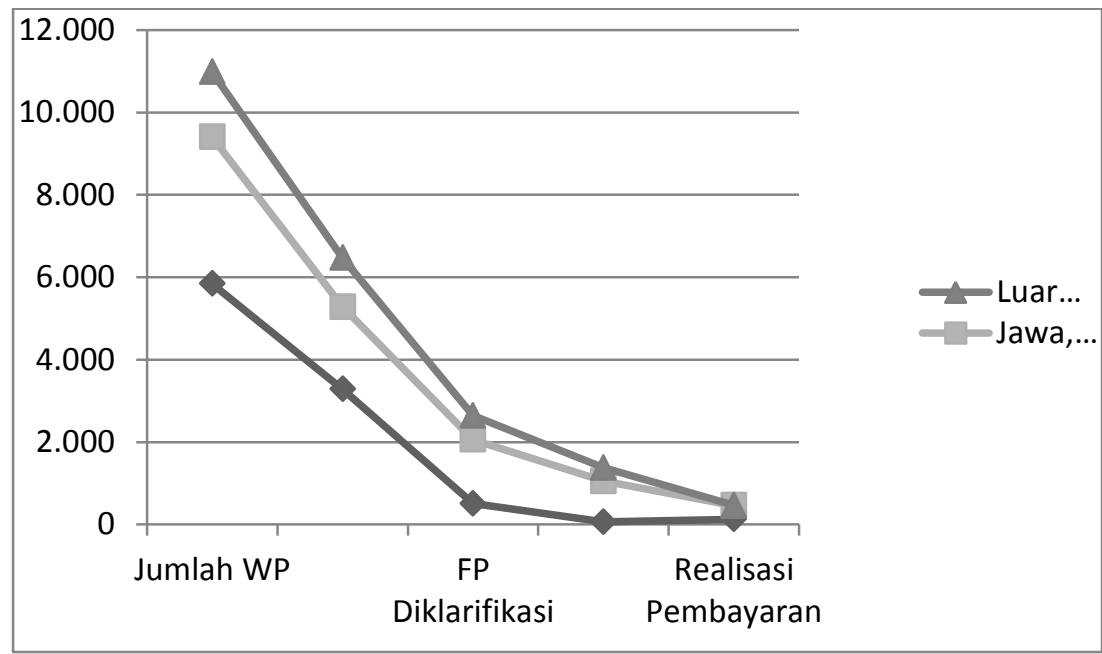

Sumber : Olahan Penulis

Dengan begitu diharapkan mampu meningkatkan kepuasan Wajib Pajak dan mereka cenderung akan lebih patuh dalam memenuhi kewajiban perpajakannya. Dengan memberikan kemudahan dalam melaksanakan kewajiban perpajakannya khususnya E-Faktur diharapkan mampu meningkatkan kepatuhan PKP dalam melaksanakan kewajiban perpajakannya. Dan hal tersebut diharapkan dapat mendongkrak penerimaan Negara. Kepatuhan yang tercipta atas kenyamanan Wajib Pajak menjalankan kewajibannya adalah kepatuhan yang bertahan. Dalam hal ini Direktorat Jenderal Pajak diharapkan dapat terus memperbaiki sistem teknologinya agar Wajib Pajak dapat terus merasakan kenyamanan dalam menjalankan kewajiban E-Faktur ini. Seperti yang disampaikan bapak Ajat Sudrajat S.Ap, M.Ak (Dosen Perpajakan Institut STIAMI), “...Untuk DJP, ada perbaikan secara contunie. Diperbaiki teknologinya. Karna kalau maintenance down itu yang dirugikan Wajib Pajak, dia telat bayar bisa kena sanksi....'(Wawancara 12 Januari 2017, 19.00 WIB).

Untuk itu dalam pelaksanaannya diperlukan kerjasama antara instasi dengan instasi di Direktorat Jenderal Pajak, dan Direktorat Jenderal Pajak dengan Wajib Pajak agar E-Faktur ini dapat sepenuhnya berlaku sesuai tujuan awal dibuatnya kebijakan tersebut.

Dalam implementasi suatu kebijakan ada empat faktor yang memengaruhi, yaitu komunikasi, sumber daya, disposisi, dan struktur birokrasi. Faktor-faktor tersebut kaitannya dengan kebijakan E-Faktur di KPP Pratama Tebet sebagai berikut:

a. Komunikasi

Komunikasi yang baik sangat dibutuhkan dalam penyampaian informasi mengenai suatu kebijakan. Direktorat Jenderal Pajak harus menginformasikan kebijakan tersebut agar Wajib Pajak selaku pengguna 
Idar Rachmatulloh dan Putri Y. Pamungkas, Analisis Implementasi Kebijakan E-Faktur...

kebijakan agar dapat memahami dengan jelas isi dan maksud kebijakan tersebut. Komunikasi dalam penelitian ini mempunya dua faktor, yaitu peraturan pelaksanaan dan koordinasi antara instasi di Direktorat Jenderal Pajak.
Pertama mengenai peraturan pelaksanaan. Hal tersebut sangat penting karena kebijakan E-Faktur ini tidak akan dapat dijalankan tanpa adanya peraturan pelaksaan sebagai landasan dari dilaksanakannya kebijakan tersebut. Peraturan Pelaksanaan tersebut adalah sebagai berikut:

Tabel 1Peraturan Pelaksanaan Kebijakan E-Faktur

\begin{tabular}{|c|c|c|c|c|}
\hline No & Jenis Peraturan & Pokok Pengaturan & Nomor Peraturan & Keterangan \\
\hline 1. & $\begin{array}{l}\text { Undang-Undang } \\
\text { Pajak Pertambahan } \\
\text { Nilai }\end{array}$ & $\begin{array}{l}\text { Perubahan } \text { Ketiga atas UU } \\
\text { Nomor } 8 \text { TAHUN } 1983 \\
\text { tentang PPN Barang dan Jasa } \\
\text { dan PPnBM }\end{array}$ & $\begin{array}{l}\text { UU No.42 } \\
\text { Tahun } 2009\end{array}$ & $\begin{array}{l}\text { Ditetapkan } \\
1 \text { April } 2010\end{array}$ \\
\hline 2. & $\begin{array}{l}\text { Peraturan Mentri } \\
\text { Keuangan }\end{array}$ & $\begin{array}{l}\text { Tata Cara Pembuatan } \\
\text { dan Tata Cara } \\
\text { Pembetulan atau } \\
\text { Penggantian Faktur Pajak }\end{array}$ & $\begin{array}{l}\text { PMK- } \\
\text { 151/PMK.03/2013 }\end{array}$ & $\begin{array}{l}\text { Ditetapkan } \\
11 \text { November } \\
2013\end{array}$ \\
\hline 3. & $\begin{array}{l}\text { Peraturan } \\
\text { Direktorat Jenderal } \\
\text { Pajak }\end{array}$ & 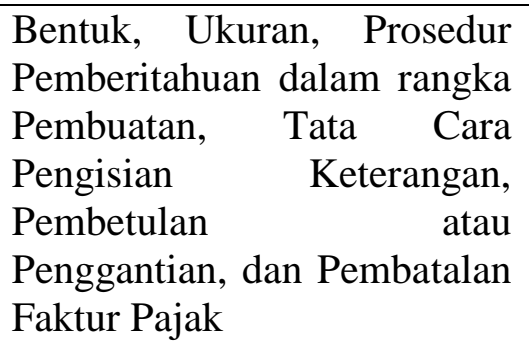 & PER-17/PJ/2014 & $\begin{array}{l}\text { DItetapkan } \\
\text { 20 Juni } 2014\end{array}$ \\
\hline 4. & $\begin{array}{l}\text { Peraturan } \\
\text { Direktorat Jenderal } \\
\text { Pajak }\end{array}$ & $\begin{array}{l}\text { Tata Cara Pembuatan dan } \\
\text { Pelaporan Faktur } \\
\text { berbentuk Elektronik. }\end{array}$ & PER-16/PJ/2014 & $\begin{array}{l}\text { Ditetapkan } \\
\text { 20 Juni } 2014\end{array}$ \\
\hline
\end{tabular}

Sumber : Olahan Penulis

Dari tabel di atas ada ada peraturan yang menonjolkan bagaimana e-Faktur tersebut akan diterapkan. Peraturan tersebut yaitu, PER-16/PJ/2014

yang ditetapkan pada 20 Juni 2014

\section{Pasal 1}

(1) Faktur Pajak berbentuk elektronik, yang selanjutnya disebut e-Faktur, adalah Faktur Pajak yang dibuat melalui aplikasi atau sistem elektronik yang ditentukan dan/atau disediakan oleh Direktorat Jenderal Pajak.
(2) Pengusaha Kena Pajak yang diwajibkan membuat e-Faktur adalah Pengusaha Kena Pajak yang telah ditetapkan dengan Keputusan Direktur Jenderal Pajak.

(3) Aplikasi atau sistem elektronik yang ditentukan dan/atau disediakan oleh Direktorat Jenderal Pajak sebagaimana dimaksud pada ayat (1) dilengkapi dengan petunjuk penggunaan (manual user) yang merupakan satu kesatuan dengan aplikasi atau sistem elektronik tersebut.

Dengan adanya perubahan dari Faktur Pajak ke dalam e-Faktur ini membuat 
Jurnal Ilmiah Untuk Mewujudkan Masyarakat Madani ISSN 2355-309X

perubahan dari yang awalnya manual dan menggunakan kertas, sekarang menggunakan teknologi seperti komputer ataupun laptop. Ternyata prakteknya beberapa mengalami kesulitan seperti ungkapan Rima Olyvia, S.E (Pegawai bagian Keuangan PT, ABC), “...Lebih mudah untuk yang memang bisa menggunakannya..Tapi pegawai keuangan kan tidak semua muda-muda. Kadang ada yang memang sudah berumur memang agak sulit mempelajari teknologi..." (Wawancara 11 Januari 2017, 09.25 WIB).

Maka dari itu perlunya kesinambungan atas sosialisasi dari KPP Pratama Tebet untuk lebih memperhatikan situasi-situasi seperti ini yang terjadi dilapangan. Implementasinya akan lebih nyata dan dapat dievaluasi untuk kemudian jika pihak KPP memperhatikan hal-hal mendalam seperti ini.

Sumber Daya

Dalam kaitannya dengan sumber daya, terdapat tiga sumber daya penting yang menentukan keberhasilan pelaksanaan suatu kebijakan. Sumber daya tersebut adalah sumber daya manusia, sumber daya keuangan, dan sumber daya sarana dan prasarana. Keberadaan sumber daya manusia dalam implementasi suatu kebijakan memegang kunci penting.

Sumber daya manusia yang dimaksud dalam hal ini adalah staf atau pegawai instasi terkait kebijakan tersebut. Sumber daya manusia merupakan faktor aktif yang bertugas mengelola dan memberdayakan faktor-faktor lainnya. Staf atau pegawai yang memadai dan kompeten dibidangnya sangat dibutuhkan agar suatu kebijakan dapat berjalan dengan baik.

Sejauh ini ketersediaan manusia dari segi kuantitas sudah memadai. Akan tetapi untuk segi kualitas sumber daya manusia pada instansi pengawasan sedikit kurang. Hal ini dapat dilihat dari kurangnya pengawasan yang diberikan, sehingga sosialisasi menjadi kurang maksimal. Apabila ada wajib pajak yang tidak atau belum dapat hadir dalam sosialisasi seharusnya dapat disampaikan mengenaik e-faktur ini pada saat company visit dan sebagainya. Sedangkan untuk bagian pelayanan sudah cukup baik, seperti dikemukakan Richwantoro, S.SI. (Kepala Seksi Pelayanan KPP Pratama Tebet). “...Kami pasti selalu memberi solusi semaksimal mungkin ya, ya paling untuk saat ini kamu bantu dengan pemberian format error yang mungkin terjadi serta penangannya...." (Wawancara 03 Januari 2017, 14.30 WIB).

Tapi ada hal berbeda yang dirasakan oleh wajib pajak yang mengalami kesulitan atas implementasi tersebut, seperti diungkapkan Duwi Larasati, S.E (Pegawai bagian Pajak PT, Indonesia Sejahtera), “...Kriing Pajak susah sekali untuk nyambung telponnya. Paling disuruh sabar sabar saja, masih kurang menurut saya...."(Wawancara 09 Januari 2017, 15.30 WIB).

Selanjutnya sumber daya keuangan. Sumber daya keuangan juga merupakan faktor penting. Karna sumber daya keuangan ini dibutuhkan untuk mendukung kegiatan operasional sehari-hari seperti pengadaan sarana dan prasarana, biaya transportasi, maupun biaya sosialisasi. Biaya ini seharusnya mencukupi untuk melakukan sosialisasi yang lebih mendalam kepada wajib pajak dalam hal pengetahuan seputar e-faktur, seperti diungkapkan Richwantoro, S.SI (Kepala Seksi Pelayanan KPP Pratama Tebet), “...Kita lakukan sosialisasi kepada wajib pajak, itu kan ada pendanaannya dari atas, kita lakukan semaksimal mungkin, disitu kita maksimalkan pemberian pengetahuan efaktur ini...." (Wawancara 03 Januari 2017, 14.30 WIB).

Sumber daya terakhir yaitu sumber daya sarana dan prasarana. Sarana dan prasarana sangat dibutuhkan dalam penentu keberhasilan suatu implementasi. Saat ini sarana dan prasarana sudah mencukupi. Karna sarana dan prasan sudah tidak perlu lagi ditambahkan. Bahkan karna sistem saat ini berbasis elektronik jadi tidak lagi 
Idar Rachmatulloh dan Putri Y. Pamungkas, Analisis Implementasi Kebijakan E-Faktur...

membutuhkan sarana dan prasarana tambahan. Hanya perlu ditingkatkan dalam bidang teknologi. Sering adanya error maintenance itu merupakan kerugian bagi wajib pajak. Direktorat Jenderal Pajak seharus memperbaiki teknologi yang ada sehingga tidak ada lagi masalahmasalah terkait sistem ini.

\section{Disposisi}

Implementor harus memiliki sikap positif terhadap implementasi kebijakan agar kebijakan tersebut kemungkinan besar akan berjalan secara efektif. Sebagai implementor tidak hanya harus memiliki kemampuan untuk melaksanakannya tetapi juga kemauan untuk melaksanakan kebijakan tersebut. Jika implementor menentang atas adanya kebijakan tersebut maka proses implementasi akan menjadi semakin sulit. Tanpa adanya dukungan, maka pelaksana akan merasa terpaksa dalam menjalankan tugasnya, sehingga tidak bisa secara penuh melaksanakan kewajibannya. Dari kebijakan tersebut apabila semua pihak merasakan manfaat atau terbantu atas kebijakan ini maka akan otomatis berarti mereka mendukung adanya kebijakan ini. Hal tersebut terlihat dari pernyataan yang disampaikan oleh Ahmad Rudi Hartono S.E., S.Kom., M.TI (Kepala Sub-Direktoral Teknologi Informasi Perpajakan DJP Kanwil Khusus), “...Sudah seharusnya Wajib Pajak terbantu. Karna kan sistem ini dapat memudahkan pembuatan Faktur Pajak. Terus juga paperless sudah tidak perlu dicetak lagi. Dan juga kita sangat mendukung kebijakan ini, karna pengawasan jadi lebih mudah...." (Wawancara 03 Januari 2017, 10.00 WIB).

Dari pernyataan tersebut dapat dilihat bahwa pihak pelaksana kebijakan telah memberi dukungan yang positif mengenai diterapkannya kebijakan e-faktur ini. Dalam kasus ini e-faktur juga memberikan dampak yang positif kepada wajib pajak, seperti diungkapkan Adzam Hafis, S. E. I (Pegawai bagian Pajak PT Tebet Indraya), “...Saya sih ya merasa sangat dimudahkan, karena kan tinggal input $\mathrm{BKP} / \mathrm{JKP}$ nya nanti nomor fakturnya sudah menyesuaikan sendiri di settingan awalnya...."(Wawancara 03 Januari 2017, 13.00 WIB).

Pernyataan di atas menjelaskan bahwa wajib pajak setuju dengan kebijakan tersebut dan merasa sangat terbantu sebagai perkembangan teknologi pada bidang perpajakan. Namun hal tersebut juga harus dibarengi dengan usaha Direktorat Jenderal Pajak untuk meningkatkan sistem sehingga tidak terjadi error-error yang pada akhirnya merugikan wajib pajak tersebut. Wajib pajak pun berpendapat dengan adanya kebijakan ini biaya-biaya berkurang karna paperless. Hal tersebut juga lebih ramah lingkungan dengan sedikitnya penggunaan kertas dalam pelaporan faktur pajak.

\section{Struktur Birokrasi}

Karkteristik struktur birokrasi pertama adalah Standar Operating Procedure (SOP). SOP berperan untuk memberikan acuan tindakan terorganisir, sehingga setiap pelaksana kebijakan akan melaksanakan tindakan terkordinir dan lebih terarah sebagai upaya pencapaian kebijakan. Dengan adanya SOP, pelaksana kebijakan dapat mengoptimalkan waktu yang tersedia dan dapat berfungsi dengan efektif untuk penerapan peraturan. Maksud dari penjelasan tersebut adalah dalam melaksanakan suatu kebijakan harus menyiapkan suatu peraturan yang dapat mengorganisasikan seluruh pelakasana kebijakan yang ada sehingga kebijakan tersebut dapat berjalan dengan baik. Seperti pendapat Agus Rachman S.Kom, M.Kom (Kepala Seksi Pengolahan Data dan Informasi KPP Pratama Tebet), “...Ya jelas sudah ada. Kebijakan tidak dapat berjalan tanpa adanya aturan yg mengikat. Mungkin SOP disini yang dimaksud adalah cara caranya gimana bisa menggunakan e-faktur, itu semua udah ada, dan udah kita shareing ke wajib pajak..." (Wawancara, 03 Januari 2017, $13.30 \mathrm{WIB})$.

SOP tersebut merupakan hasil dari kebijakan yang telah disusun kemudian dijabarkan dalam suatu prosedur sehingga 
Jurnal Ilmiah Untuk Mewujudkan Masyarakat Madani

ISSN 2355-309X

dapat langsung dilaksanakan oleh para pelaksana kebijakan.

Yang juga berkaitan dengan struktur birokrasi adalah pola hubungan antar unit- unit di dalam organisasi. Dalam kaitannya dengan penelitian ini, sudah terdapat pola hubungan di dalam organisasi yang melaksanakan kebijakan e-faktur ini.

Tabel 2

Matriks Hasil Penelitian

\begin{tabular}{|c|c|c|c|}
\hline Faktor & $\begin{array}{l}\text { Keterangan } \\
\text { Faktor }\end{array}$ & Indikator & $\begin{array}{l}\text { Keterangan } \\
\text { Indikator }\end{array}$ \\
\hline 1. Komunikasi & $\checkmark$ & $\begin{array}{l}\text { a. Keberadaan peraturan } \\
\text { pelaksanaan }\end{array}$ & $\checkmark$ \\
\hline $\begin{array}{l}\text { 2. Sumber } \\
\text { Daya }\end{array}$ & $\checkmark$ & $\begin{array}{ll}\text { a. } & \text { Sumber Daya } \\
\text { Manusia } \\
\text { b. Sumber Daya } \\
\text { Finansial } \\
\text { c. Sarana dan Prasarana }\end{array}$ & $\begin{array}{l}\checkmark \\
\checkmark \\
\checkmark\end{array}$ \\
\hline 3. Disposisi & $\checkmark$ & $\begin{array}{l}\text { a. Respon Implementor } \\
\text { Terhadap Kebijakan } \\
\text { b. Pemahaman Terhadap } \\
\text { Kebijakan } \\
\text { c. Transparasi }\end{array}$ & $\begin{array}{l}\checkmark \\
\checkmark \\
\checkmark\end{array}$ \\
\hline $\begin{array}{ll}\text { 4. } & \text { Struktur } \\
\text { Birokrasi }\end{array}$ & $\checkmark$ & $\begin{array}{ll}\text { a. } & \text { Tersedia SOP } \\
\text { b. } & \text { Hubungan dalam } \\
\text { Organisasi }\end{array}$ & $\begin{array}{l}\checkmark \\
\checkmark\end{array}$ \\
\hline
\end{tabular}

Sumber : Diolah Penulis

Keterangan : $\checkmark$ : Terpenuhi

$\mathrm{X}$ : Tidak Terpenuhi

Dari tabel di atas mengenai matriks hasil penelitian diketahui bahwa semua dimensi dalam penelitian sudah terpenuhi. Dimensi komunikasi, keberadaan peraturan pelaksana sudah terpenuhi. Untuk dimensi kedua sumber daya, seluruhnya terpenuhi, yang terdiri dari sumber daya manusia, sumber daya finansial, dan sumber daya sarana dan prasarana. Selanjutnya untuk dimensi ketiga disposisi, respons implementor, pemahaman terhadap kebijakan, dan transparansi juga terpenuhi. Dan yang terakhir struktur birokrasi untuk kedua indikatornya prosedur dan hubungan dalam birokrasi terpenuhi.

Faktor-Faktor Penghambat yang Terjadi Selama Implementasi Kebijakan E-Faktur
E-Faktur dapat dikatakan merupakan suatu kebijakan yang masih baru. Dapat dikatakan e-faktur belum dapat berjalan secara optimal. Hal tersebut dapat dilihat dari masih adanya kendala-kendala dalam pelaksanaannya. Berdasarkan hasil penelitian kendala-kendala yang menjadi penghambat dalam pelaksanaan kebijakan e-faktur ini adalah sebagai berikut :

Error Aplikasi

Error pada aplikasi yang diberikan oleh Direktorat Jenderal Pajak ini menjadi suatu penghambat kelancaran penerapan kebijakan ini. Seperti disampaikan oleh Fauziah (Pegawai bagian Keuangan PT. XXX), “...Dan juga itu aplikasi sering sekali 
Idar Rachmatulloh dan Putri Y. Pamungkas, Analisis Implementasi Kebijakan E-Faktur...

error, $\quad$ ETAX-1001, ETAX1002..."(Wawancara 06 Januari 2017).

Dari pernyataan tersebut dapat diketahui bahwa aplikasi tersebut masih memiliki kendala dalam pengaplikasiannya. Error tersebut berkaitan dengan kepatuhan wajib pajak. Karena jika error-error ini terus berlangsung tanpa adanya pembenahan dari pihak DJP makan kepatuhan wajib pajak dapat menurun. Hal tersebut tentu akan memengaruhi penerimaan Negara. Jika wajib pajak patuh dengan kenyamanan penuh, maka dapat dipastikan hal tersebut akan berlangsung lama dan tidak terhenti.

Kendala tersebut juga dirasakan oleh Muhammad Zaki, S.E, M.AK (Pegawai bagian Pajak PT. G). seperti disampaikan sebagai berikut: “...Aplikasi juga kadang suka error kalau habis di update. Seperti itu, jadi kendala juga di kita...."(Wawancara 11 Januari 2017, 12.00 WIB).

Menurut pendapat tersebut terlihat bahwa error aplikasi ini terjadi pada beberapa wajib pajak. Tidak menutup kemungkinan bahwa hal yang sama terjadi pula pada wajib pajak yang lainnya.

\section{Error Maintanance}

Error maitanance ini bukan hal baru lagi bagi penerapan kebijakan e-faktur. Semenjak penerapan berskala nasional pada 1 Juli 2016 banyak sekali berita-berita pada kanal online maupun Koran membicarakan hal ini. Kelebihan beban pada server ini yang menjadi kendala, dikarenakan banyaknya wajib pajak yang menggunakan e-faktur pada satu waktu yang bersamaan. Begitu pula yang dirasakan oleh wajib pajak Muhammad Zaki, S.E, M.AK (Pegawai bagian Pajak PT. Bumi Mandiri) berikut: “...Masih banyak yang harus dibenahi, seperti peningkatan server agar tidak sering-sering maintenance. Seperti itu, jadi kendala juga di kita. Karna kan kalau maintenance di akhir akhir waktu itu membuat kita jadi telat lapor, bisa sanksi...." (Wawancara 11 Januari 2017, 12.00 WIB).
Menurut pendapat tersebut dapat diketahui bahwa hal ini dapat merugikan pihak wajib pajak. Karna apabila terjadi error yang dapat menyebabkan wajib pajak telat lapor akan mendapatkan sanksi 2\% dari DPP. Itu dapat merugikan tergantung seberapa besar DPP yang tercantum pada faktur pajak tersebut.

Dari pihak Direktorat Jenderal Pajak mengkonfirmasi tentang adanya error ini. Seperti disampaikan oleh Ahmad Rudi Hartono S.E., S.Kom., M.TI (Kepala Sub Direktoral Teknologi Informasi Perpajakan DJP Kanwil Khusus), “...Kan e-Faktur ini juga buatan manusia ya pasti ada minus minusnya satu dua. Error untuk aplikasi dan maintanance itu yang paling sering kami terima. Kita akan terus meningkatkannya, apalagi keluhan Wajib Pajak itu kan kita gak lewatkan begitu saja, kita tampung, kita kembangkan lagi nanti ke depannya. Saya pribadi berharap Wajib Pajak dapat mengerti memang bahwa sistem kita ini kan masih kecil kalau dibandingkan dengan harus menampung sekian banyaknya Wajib Pajak, jadi bila melakukan koneksi ke DJP bersamaan dalam satu waktu ya memang kadang suka error seperti itu...." (Wawancara 03 Januari 2017, 10.00 WIB).

Pernyataan tersebut menjelaskan bahwa memang dalam sistem di DJP masih belum bisa menampung sekian banyaknya wajib pajak yang terkoneksi secara bersamaan di satu waktu yang sama. Pihak KPP Pratama Tebet menegaskan akan diadakannya perbaikan melalui Agus Rachman S.Kom, M.Kom (Kepala Seksi Pengolahan Data dan Informasi (KPP Pratama Tebet) menyebutkan, "...kita usahakan sampai detik ini. Kita ada rencana untuk penambahan server master untuk pencegahan terjadinya kelebihan beban akses yang menyebabkan maintenance itu...."(Wawancara 03 Januari 2017, 13.30 WIB).

Keterangan di atas menunjukan bahwa KPP Pratama Tebet akan terus memperbaiki sistem yang akan menunjang kelancaran implementasi kebijakan tersebut. Server dan 
Jurnal Ilmiah Untuk Mewujudkan Masyarakat Madani

ISSN 2355-309X

pengembangan teknologi memang sangat dibutuhkan pada penerapan kebijakan berbasis elektronik.

\section{Target Penerimaan di KPP Pratama Tebet Pasca Diberlakukannya E-Faktur}

Dalam hal ini e-faktur terbukti dapat menjadi salah satu fasilitas dari Direktorat Jenderal Pajak. Hal ini terbukti dari data penerimaan yang dihimpun oleh DJP Kanwil Khusus sebagai berikut :

Gambar IV

Grafik Penerimaan Negara Tahun 2014 - 2016

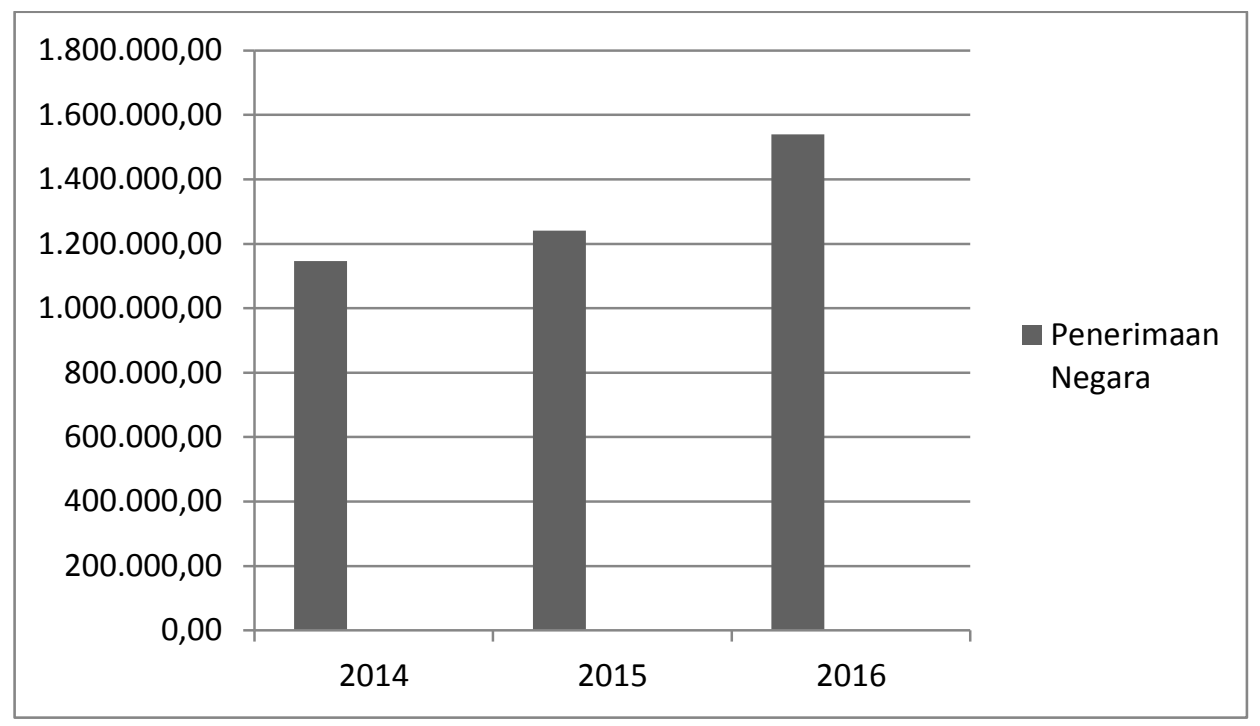

Sumber : Olahan Penulis

Dari data tersebut dapat dilihat bahwa pada tahun 2015 saat e-faktur diterapkan tahap pertama di Jawa dan Bali menurun dari tahun 2014 karena e-faktur belum diberlakukan. Tetapi pada tahun 2016 saat efaktur ditetapkan skala nasional, penerimaan Negara meingkat $12,40 \%$. Hal ini menjelaskan bahwa e-faktur dapat membantu untuk meningkatkan penerimaan Negara. Seperti yang disampaikan oleh Ajat Sudrajat S.Ap, M.AK (Dosen Perpajakan Institut STIAMI), “...Seharusnya penerimaan Negara meningkat, e-Faktur meminimalisir adanya Faktur Pajak fiktif, jadi e-faktur itu lebih mudah disetor dan dilapor, jadi lebih terkontrol...." (Wawancara 12 Januari 2017, 19.00 WIB).

Dari pernyataan tersebut dapat diambil kesimpulan bahwa berkurangnya penyalah gunaan faktur pajak fiktif dapat sangat membantu penerimaan Negara. Karena berkat itu kas Negara yang seharusnya masuk tidak akan diambil secara tidak benar oleh oknum - oknum faktur pajak fiktif. Hal tersebut dikonfirmasi oleh pihak DJP Ahmad Rudi Hartono S.E., S.Kom., M.TI. (Kepala Sub Direktoral Teknologi Informasi Perpajakan (DJP Kanwil Khusus), “...Terlihat peningkatannya. Penerimaan Negara menigkat walupun tidak signifikan langsung.Misi awalnya e-Faktur kan untuk memberantas Faktur Faktur Pajak Fiktif, untuk itu ini bisa dibilang goal. Karna jelas Faktur Pajak Fiktif berkurang drastis...." (Wawancara 03 Januari 2017, 10.00 WIB).

Dari pendapat tersebut dapat dilihat bahwa visi awal pembuatan kebijakan efaktur ini terpenuhi, yaitu penghapusan faktur pajak fiktif. Persoalan penerimaan Negara itu fleksibel langsung mengikuti.

\section{Simpulan}

Berdasarkan hasil penelitian yang telah dijelaskan dalam bab IV (empat), maka dapat dipetik beberapa kesimpulan penelitian mengenai implementasi kebijakan e-faktur di 
Idar Rachmatulloh dan Putri Y. Pamungkas, Analisis Implementasi Kebijakan E-Faktur...

KPP Pratama Tebet Jakarta. Adapun kesimpulan sebagai berikut:

1. Sistem implementasi e-faktur pada KPP Pratama Tebet telah memenuhi semua dimensi dalam penelitian sudah terpenuhi. Dimensi komunikasi, keberadaan peraturan pelaksana sudah terpenuhi. Untuk dimensi kedua sumber daya, seluruhnya terpenuhi, yang terdiri dari sumber daya manusia, sumber daya finansial, dan sumber daya sarana dan prasarana. Selanjutnya untuk dimensi ketiga disposisi,respon implementor, pemahaman terhadap kebijakan, dan transparansi juga terpenuhi. Dan yang terakhir struktur birokrasi untuk kedua indikatornya prosedur dan hubungan dalam birokrasi terpenuhi.

2. Sebagai sebuah kebijakan yang mengalami perubahan perubahan, e-faktur di hadapkan pada hambatan.

a. Error Aplikasi

\section{b. Error Maintanance}

3. Pada tahun 2015 saat e-faktur diterapkan tahap pertama di Jawa dan Bali menurun dari tahun 2014 dimana e-faktur belum diberlakukan. Tetapi pada tahun 2016 saat e-faktur ditetapkan skala nasional, penerimaan Negara meingkat $12,40 \%$. Hal ini menjelaskan bahwa e-faktur dapat membantu untuk meningkatkan penerimaan Negara.

\section{Saran}

Berdasarkan kesimpulan di atas direkomendasikan beberapa saran sebagai berikut :

1. Sosoalisasi menyeluruh yang diperuntukan secara keseluruhan bagi wajib pajak selaku penjual Barang Kena Pajak dan/atau Jasa Kena Pajak dan juga pembeli yang melakukan pembelian atas Barang Kena Pajak dan/atau Jasa Kena Pajak
2. Adanya perbaikan secara terus menerus teknologi yang ada di dalam Direktorat Jenderal Pajak agar penerapan sistem efaktur ini dapat berjalan secara maksimal.

3. Menciptakan kembali sistem-sistem seperti e-faktur ini, untuk memudahkan wajib pajak menjalankan kewajibannya di bidang perpajakan, sehingga dapat meningkatkan penerimaan Negara.

\section{DAFTAR PUSTAKA}

\section{Buku}

Abdul R. (2010). Panduan Pelaksanaan Administrasi Pajak Untuk Karyawan, Pelaku

Bisnis dan Perusahaan. Bandung, Nuansa

Faried Ali. (2011) Teori dan Konsep Administrasi: dari Pemikiran Paradigmatik

menuju Redefinisi, Jakarta: PT. Raja Grafindo Persada

Gaffar, Afan, (2009). Politik Indonesia: Transisi Menuju Demokrasi, Yogyakarta,

Cetakan V, Pustaka Pelajar.

Hamdi, Muchlis. (2014). Kebijakan publik: proses, analisis, dan partisipasi. Bogor:

Ghalia Indonesia.

Indiahono, Dwiyanto. (2009). Kebijakan Publik Berbasis Dynamic Policy Analysis.

Yogyakarta: Gava Media.

Mardiasmo. (2013). Perpajakan Edisi Revisi, Andi Offset, Yogyakarta.

Pramana, R. (2008). Penerapan Aplikasi Surat Pemberitahuan Masa Elektronik (e 
Jurnal Ilmiah Untuk Mewujudkan Masyarakat Madani

ISSN 2355-309X

SPT) Pajak Pertambahan Nilai Dan Pengaruhnya Terhadap Kepatuhan Pemenuhan Kewajiban Perpajakan.

Rosdiana dan Irianto. (2012). Pengantar Ilmu Pajak, Kebijakan dan Implementasi Di

Indonesia, PT. RajaGRafindo Persada.

Resmi,Siti. (2013). Perpajakan Teori dan Kasus. Salemba Empat. Jakarta

Resmi, S. (2009). Perpajakan : Teori Dan Kasus. Jakarta: Salemba Empat.

Suwandy, E. (2008). Hukum Pajak . Jakarta: Salemba Empat.

Waluyo. (2011). Perpajakan Indonesia. Jakarta: Salemba Empat.

\section{Internet}

http://merrydewiputri.com/2016/01/15/pengar uh-e-faktur-terhadap-perencanaanpajak-khususnya-ppn/ https://www.linkedin.com/pulse/e-faktur2015-dalam-serba-serbi-mc-lim

http://ekstensifikasi423.blogspot.co.id/2015/0 1/faktur-pajak-dan-e-faktur-pajak.html

http://www.ortax.org/ortax/?mod=forum\&pag $\mathrm{e}=$ show \&idtopik $=60982 \& \mathrm{hlm}=2$

\section{Dokumen}

Peraturan Mentri Keuangan PMK151/PMK.03/2013

Peraturan Direktorat Jenderal Pajak PER17/PJ/2014

Peraturan Direktorat Jenderal Pajak PER$16 / \mathrm{PJ} / 2014$

Skripsi Ahmad Shaugi 2012 Universitas Indonesia

Undang-Undang Pajak Pertambahan Nilai UU.No.42 Tahun 2009 